\title{
Root Cause of Diseases - Ama Concept W.S.R to Free Radical Theory
}

\section{Review Article}

\section{Jaideep Sapra $^{1^{*}}$}

1. Associate Professor (Reader), Department of Kayachikitsa,

Shaheed Kartar Singh Sarabha Ayurvedic Medical College, Sarabha, Ludhiana, Punjab.

Email- jaisapra5@gmail.com

\begin{abstract}
Ayurveda speaks the main cause of diseases is rooted in the impairment of the body's main fire, called Agni, the fire of digestion. Ayurveda views the health of the body as the functioning of a biological fire-governing metabolism. If this essential part is functioning effectively, the whole body will be nourished, full of life and vibrancy. Altered digestive functioning can lead to the production of Ama, a toxic material that initiates and promotes disease processes throughout the body. In the same way, free radicals are also found to be the root cause of many diseases. The majority of free radicals that damage biological systems are oxygen-free radicals, and these are more generally known as "Reactive oxygen Species" (ROS). These are the main byproducts formed in the cells of aerobic organisms, and can initiate autocatalytic reactions so that molecules to which they react are themselves converted into free radicals to propagate the chain of damage. Here we shall discuss about properties of both Ama and Free Radicals. The present article attempts to correlate the concept of Free radical with the concept of Ama.
\end{abstract}

Keywords: Agni, Ama, Free radicals, ROS

\section{Introduction}

\section{Concept of Ama}

According to Ayurveda proper diet and its digestion are main pillars of life. An improper diet or error in digestive process results in production of Ama, a toxic material that initiates and promotes disease processes. Whatever we ingest in our body through the mouth, in any form it does not get assimilated in the body in same form.

*Corresponding Author:

\section{Jaideep Sapra}

Associate Professor,

Department of Kayachikitsa,

Shaheed Kartar Singh Sarabha Ayurvedic

Medical College,

Sarabha, Ludhiana, Punjab

Email- jaisapra5@gmail.com
The ingested food material undergoes a series of physical and chemical transformation before it is rendered acceptable by the body tissues. The transformation takes place by the action of a particular Agni on the ingested food material of particular substance. The transformation process entirely, depends upon the strength of this Agni. Stronger the Agni, quicker is the transformation and better transformation too. If this Agni is weak the transformation will be incomplete. Concept of Ama (1)has been stressed in Ayurveda with its vast application. Ama (as per the different classics) can be understood as:-

Incompletely digested food, Un-processed food,

Food which is undergoing the process of digestion, 
Partially digested,

Matter which requires further

\section{Parinama.}

When this entity is retained in the body, it gradually produce impairment in the micro and macro channels of the body. It creates the condition of Srotovaigunya that can lay the foundation of disease processes or can be converted into any form of disease (2). This is the why Ayurveda has given much importance to the concept of Ama. As per the contemporary physiology a variety of transforming substances are present in the body like various enzymes, hormones, catalysts etc. When these are unable to function properly then different metabolites are formed which are not acquired by the body, further these go on accumulating in different systems affecting their normal functions. As per Ayurveda these can be considered as Ama.

\section{Concept of Free Radicals}

Oxygen, which is an indispensable element for life, can under certain situations cause severe deleterious effects in the human body. Most of the potentially harmful effects of the oxygen are due to the formation and activity of number of chemical compounds, known as Reactive oxygen species (ROS), which have tendency to donate oxygen to other substances resulting in formation of oxygen radicals and several non-radical oxidizing agents such as HOCI (Hypochlorous acid), hydrogen peroxide, ozone, etc. Many such reactive species are free radicals and have a surplus of one or more free floating electrons rather than having matched pairs and are therefore, unstable and highly reactive. This unstable configuration creates energy which is released through reactions with adjacent molecules, such as proteins, lipids, carbohydrates, and nucleic acids. These are the main byproducts formed in the cells of aerobic organisms, and can initiate autocatalytic reactions so that molecules to which they react are themselves converted into free radicals to propagate the chain of damage.

A wide variety of oxygen free radicals and other reactive species can be formed in the human body and food system. Ama is not a single entity but is a generalized term which can be applicable for many malformed substances in the body and responsible for the production of various diseases. In the same way free radicals are also found to be the root cause of many diseases in contemporary science $(3,4,5)$

\section{Discussion}

\section{Similarities in ama-free radical Cause of formation: \\ Manas hetu}

Consumption of food in state of mental stress due to Kama, Krodha, Lobha, Moha, Irshaya, Shoka, Bhaya, Lajja, Chinta, Mano Udvega, Manoglani (6) etc are important factors responsible for indigestion of food and production of Ama in the body.

Mental stress is known to trigger or enhance the production of Free Radical.

\section{Mithya ahara}

Improper dietary habits cause Agnimandata leading to the production of Ama (7)

The types of food we eat can alter the degree of oxidative stress in the body. For example, 'advanced glycation end products' (AGE's) that are formed during the frying/ crisping of foods increase oxidative stress in the body so can lead to production of Free Radicals.

Also Exogenous factors like preservatives used in certain food products of today's instant and ready to eat food, pollutants, tobacco, smoke, drugs, xenobiotics, or radiation etc. lead to the formation of Free- radical .

\section{Visha/Toxins (8)}

Ama may be formed in the body as a result of vishaja dravyas or combination 
of vishaj dravyas like Gara visha, visha from Viruddha ahara etc.

Similarly certain toxic substances like heavy metal produce free radicals. Auto-oxidation, consequent inactivation of small molecules such as reduced thiols, flavins and electron transfer etc. are few such processes that trigger free radicals inside the body.

\section{Mode of Production}

Ama:

Ama is produced due to inequilibrium of Agni at various levels.

Free radical:

Free radicals are said to be produced in the body in abundance when equilibrium between its generation and body's primary defense is disturbed which includes the activity of certain enzymes like superoxide dismutase, catalase and glutathione peroxidase.

\section{Classification}

Ama

The human body contains about $10^{13}$ cells. Each cell of the body has its own Agni depending upon which many different types of Ama can be produced.

Free radical

Total number or types of free radicals are unknown. Depending upon the site and method of production many different forms of free radicals are produced.

\section{Avipakvatva (9): Ama as an intermediate metabolite}

Ama:

As per one of the definition, Ama, is a food state which is undergoing the process of digestion hence it can be considered that Ama exist in an incomplete or intermediate metabolic state. If this state remains in the body as such it can cause various diseases which has to be treated/neutralized after deepan and pachan.

\section{Free radical:}

Certain enzymes produce radicals as intermediary substances, which are supposed to go into further metabolism, but they somehow jump out of the normal metabolic cycle and work as harmful entities.

\section{State of their existence:}

Both Ama and Free Radical when produced, remains in Free State and hence termed asamyuktam.

\section{Similarities in Guna of Ama and Free} Radical

\section{Daurgandhaya (10)}

Ama:

Ama being impartially processed metabolite has a quality Durgandha.

\section{Free radical:}

Free radical causes the damage to cell membrane and leads to putrefaction as well as foul smell formation.

\section{Bahupicchil (11)}

Ama:

Ama sticks to normal healthy body tissues very quickly due to its picchil quality.

\section{Free radical:}

To seek stability in their structure Free radicals try to quickly stick to the healthy molecules thereby attacking the body and thus setting a chain reaction of destruction.

\section{Sadan sarvagatra (12)}

Ama:

\section{Free radical:}

Ama affects the whole body tissues.

Free radicals can also damage the cells of body.

\section{Similarities in Treatment Free Radical:}

Antioxidant is the answer to prevent body from the deleterious effects of Free Radicals. An antioxidant is a molecule that inhibits the oxidation of other molecules. 
Oxidation is a chemical reaction involving the loss of electrons or an increase in oxidation state. Oxidation reactions can produce free radicals. In turn, these radicals can start chain reactions. When the chain reaction occurs in a cell, it can cause damage or death to the cell. Antioxidants terminate these chain reactions by removing free radical intermediates, and inhibit other oxidation reactions. They do this by being oxidized themselves, so antioxidants are often reducing agents such as thiols, ascorbic acid, or polyphenols. plants and animals maintain complex systems of multiple types of antioxidants, such as glutathione, vitamin $\mathrm{C}$, vitamin $\mathrm{A}$, and vitamin $\mathrm{E}$ as well as enzymes such as catalase, superoxide dismutase and various peroxidases. Insufficient levels of antioxidants, or inhibition of the antioxidant enzymes, cause oxidative stress and may damage or kill cells. Oxidative stress is damage to cell structure and cell function by overly reactive oxygencontaining molecules and chronic excessive inflammation. Oxidative stress seems to play a significant role in many human diseases, including cancers (13).

\section{Ama:}

Line of Treatment of Ama includes - Langhan ,Deepan, Paachan and Sodhan according to the Dosas (14). In order to find out a correlation on the basis of treatment between Ama and Free Radicals some Deepan drugs as included by Acharya Charak in Deepaniya Mahakashaya Sunthi, Chitrak, Pippali , Ama pachan properties of Mustak, as per Yaajapurishiya Adhayaya and Mishreya, which has been coded by Acharaya Sarngdhara in definition of Deepan dravyas are considered here. All of these drugs are proven to be rich in antioxidants. Action of above mentioned drugs as per Ayurvedic Classics and their antioxidants composition are as mentioned below:
Sunthi, Zingiber officinale RoscoeZingiberaceae has been included by Acharya Charak in Dipaniya Mahakasaya (15) . It contains a number of antioxidants such as beta-carotene, ascorbic acid, terpenoids, alkaloids, and polyphenols such as flavonoids, flavones glycosides, rutin, etc. Easily cultivable, Zingiber officinale with its wide range of antioxidants is a major source of natural or phytochemical antioxidants. Various studies on the antioxidant properties of ginger species had been confined only to the rhizomes, which have been reported to have tyrosinase inhibiting properties (16).

Mishreya, Foeniculum vulgare Mill.Apiaceae Acharya Sarangdhara says Mishreya possesses Dipan properties (17). It is a biennial medicinal plant belonging to the family Apiaceae (Umbelliferae) is a rich source of vitamin $\mathrm{C}$. A one cup serving of fennel bulb provides $10.5 \mathrm{mg}$ of vitamin $\mathrm{C}$, or $17 \%$ of the daily value. Vitamin $\mathrm{C}$ boosts the immune system, and also functions as an antioxidant by protecting blood vessel walls from oxidation that contributes to cardiovascular disease. Fennel provides Phytochemical, including Anethole, Rutin and Quercetin, which function as antioxidants. They protect and repair damage resulting from excessive levels of free radicals (18). Anand et al reported that fennel seed possesses anticancer activity owing to its antioxidant properties (19).

Chitrak, Plumbago zeylanica Linn.Plumbaginaceae as per Acharya Charak plant possess dipanaya, pachaniya properties and is able to cure Gudshotha, Arsha and shula (20). Various studies have shown that the root of the plant and its constituents are credited with potential therapeutic properties including antiatherogenic, cardiotonic, hepatoprotective and neuroprotective properties. Its active ingredient plumbagin have significant antioxidant abilities by free radical scavenging and superoxide radical 
scavenging assays. The plant roots extract revealed significant antioxidant activity as compared to standard flavonoid (quercetin) (21). In another study, Plumbago zeylanica, was tested for its possible in vivo protective effect against cyclophosphamide-induced genotoxicity and oxidative stress in Swiss albino mice (22).

\section{Mustak, Cyperus rotundus Linn.-} Cyperaceae is known to exhibit Samgrahi, deepaniya, pachniya properties (23). The Extract of Cyperus rotundus has analgesic, anti-inflammatory, antioxidant and immunomodulatory effects due to presence of flavonoid, tannin and polyphenol contents. (24).

\section{Pippali, Piper Longum Linn.- Piperaceae} has been included by Acharya Charak in Dipaniya Mahakasaya. The phytochemical tests in various studies indicated the presence of alkaloids, glycosides, tannins, and flavonoids in the crude ethanolic extract. Several of such compounds are known to possess potent antioxidant activity (25).

In the light of above mentioned action of Deepan and Paachan drugs and their antioxidant activity, it can be said on the basis of line of treatment also both Ama and Free radicals can again be correlated with each other.

\section{Conclusion}

Summing up above explanation it can be concluded that though Agni, the metabolic fire at various levels digests the food thoroughly and nourishes the body systems ,but hypofunction or impaired function of these Agnis at various levels is the main factor concerned in the formation of Ama i.e. improper metabolism produces Ama . Further accumulation of byproduct of metabolism as well as metabolic waste that are not properly eliminated or utilized in the body can be considered as Ama. Here it is noteworthy that whenever there will be improper metabolism due to impaired functioning of Agni then only Ama will be formed. Free radicals which are also formed as intermediary byproduct of metabolism, have the tendency to damage various cells of the body. From the entire discussion regarding the various similarities between Ama and free radicals in terms of the general definition, properties, types, site of production, mechanism of producing diseases and the line of treatment, we can say that the concept of Ama in Ayurveda can be correlated with the theory of Free radical in Modern science.

\section{References}

1. Viadya Yadunandan Upadhayaya editor Ashtanghridyam sootrsthana ch.13/25, $8^{\text {th }}$ edition page 111 Chaukhamba Prakashan, Varanasi.

2. Viadya Yadunandan Upadhayaya editor Ashtanghridyam sootrsthana ch.13/27, $8^{\text {th }}$ edition page 111 Chaukhamba Prakashan, Varanasi

3. Understanding the correlation of Ama concept and Free radical theory with a clinical interpretation review article by Mohanty Bishnupriya et al. Journal of Biological and scientific opinion volume 1 (3) 2013

4. Kumar Baldev, Dave Hetal, Kumari Madhuri. Pathological correlation between Ama and free radicals with special reference to Madhumeha. The Journal of Research and Education in Indian medicine 2008; xiv- 2:61-64 ..

5. Correlation of concept of Ama and Free radical theory- review article. Rohit Ranjan1, Sanjay Srivastava2 Int. J. Ayur. Pharma Research, 2014; 2 (2): 9-13.

6. Brahmanand Tripathi editor Charak Samhita Viman Sthana ch.2/9 Reprint edition 2015, Chaukhamba Prakashan ,Varanasi, page 671.

7. Brahmanand Tripathi editor Charak Samhita Viman Sthana ch.2/8 Reprint edition 2015, Chaukhamba Prakashan, Varanasi. page 671 
8. Viadya Yadunandan Upadhayaya editor Ashtanghrdyam sootrsthana ch.8/13, $8^{\text {th }}$ edition, Chaukhamba Prakashan,Varanasi, page 89

9. Madhavakara, Editor Yaduanadana Upadhaya, Madhava Nidan, Reprint, Vol. 1 Chap. 25/1-15 Varanasi; Chaukhambha Sanskrit Sansthan;2006 P. 508-509

10. Ibid

11. Ibid

12. Ibid

13. Wikipedia free encyclopedia -Free Radical Theory

14. Viadya Yadunandan Upadhayaya editor Ashtanghrdyam sootrsthana ch.13/25, $8^{\text {th }}$ edition page 89 Chaukhamba Prakashan, Varanasi

15. Brahmanand Tripathi editor Charak Samhita Sootra Sthana ch.4/6 Reprint edition 2015, Chaukhamba Prakashan, Varanasi page 78

16. Chemical composition and antioxidant properties of ginger root (Zingiber officinale) Shirin Adel P. R. and Jamuna Prakash -Journal of Medicinal Plants Research Vol. 4 (24), pp. 26742679, 18 .December, 2010 Available online

at http://www.academicjournals.org/JMP R DOI: 10.5897/JMPR09.464 ISSN 1996-0875@2010 Academic Journals.

17. Brahmanand Tripathi editor Sarangdhara Samhita Madhyam khanda ch. 4/1 Third edition Chaukhamba Prakashan, Varanasi page 46

18. Boloji.com properties of Herbal Fennel, Saunf -Dr. Vipul Sharma

19. Anand, P.; Kunnumakara, A.; Sundaram, C.; Harikumar, K.; Tharakan, S.; Lai, O.; Sung, B.; Aggarwal, B. Cancer is a preventable disease that requires major lifestyle changes. Pharmaceut Res. 2008, 25, 2097-2116

20. Brahmanand Tripathi editor Charak Samhita Sootra Sthana ch.25/40 Reprint edition 2015, Chaukhamba Prakashan, Varanasi page 454.

21. Plumbago zeylinica linn. (chitrak) review as rasayan (rejuvenator / antiaging) Sanjana data and Mishra RN-Review Paper International Journal of Research in Pharmaceutical and Biomedical Sciences, ISSN: 222937 Jan -March 2012

22. SivakumarV, Niranjali Devraj S. Protective effect of Plumbago Zeylanica against cyclophosphamideinduced genotoxicity and oxidative stress in Swiss albino mice.

23. Brahmanand Tripathi editor Charak Samhita Sootra Sthana ch.25/40 Reprint edition 2015, Chaukhamba Prakashan,Varanasi page 454

24. Pharmacological, antioxidant, genotoxic studies and modulation of rat splenocyte functions by Cyperus rotundus extracts Kilani-Jaziri Soumaya ${ }_{2}$ Mhalla Dhekra, Châbane Fadwa ${ }_{2}$ Ghedira Zied, Limem Ilef, Ghedira Kamel_ and ChekirGhedira Leila. B.M.C Complementary and alternative medicine journal Jan, 2013 available at http://www.biomedcentral.com/14726882/13/28.

25. Phytochemical Evaluation and Antioxidant activity of Piper cubeba and Piper nigrum, Gayatri Nahak and R.K. Sahu, Journal of Applied Pharmaceutical Science available at www.japsonline.com ISSN: 22313354 Received on: 08-10-2011 Revised on: 12:10:2011 Accepted on: 15-10-2011. 